\title{
Jumping spiders of the genus Pancorius Simon, 1902 (Araneae: Salticidae: Plexippini) from eastern India, with a description of a new species
}

\section{Пауки-скакунчики рода Рancorius Simon, 1902 (Araneae: Salticidae: Plexippini) из восточной Индии, с описанием нового вида}

\author{
John T.D. Caleb ${ }^{1}$, Chandan Bera², Shelley Acharya'2, Vikas Kumar ${ }^{1}$ \\ Ажкон Т.А. Калеб ${ }^{1}$, Чандан Бера², Шемли Ачарья², Викас Кумар ${ }^{1}$
}

\footnotetext{
${ }^{1}$ Centre for DNA Taxonomy, Zoological Survey of India, Prani Vigyan Bhawan, M-Block, New Alipore, Kolkata - 700 053, West Bengal, India. E-mail: caleb87woodgate@gmail.com

${ }^{2}$ Arachnology Division, Zoological Survey of India, Prani Vigyan Bhawan, M-Block, New Alipore, Kolkata - 700 053, West Bengal, India.
}

KEY WORDS: Aranei, Arunachal Pradesh, Nagaland, new records, taxonomy.

КЛЮЧЕВЫЕ СЛОВА: Aranei, Аруначал Прадеш, Нагаланд, новые находки, таксономия.

ABSTRACT. A new Pancorius species, P. nagaland Caleb sp.n. ( + ), is diagnosed and described from north-eastern India. Three species: Pancorius darjeelingianus Prószyński, 1992, P. magnus Żabka, 1985 and $P$. tagorei Prószyński, 1992 are illustrated and mapped. A new combination and synonymy are proposed: Pancorius pseudopaykulli Sen, Dhali, Saha et Raychaudhuri, 2015, comb.n. (ex Plexippus), and syn.n., as a junior synonym of $P$. darjeelingianus Prószyński, 1992.

How to cite this article: Caleb J.T.D., Bera Ch., Acharya Sh., Kumar V. 2019. Jumping spiders of the genus Pancorius Simon, 1902 (Araneae: Salticidae: Plexippini) from eastern India, with a description of a new species // Arthropoda Selecta. Vol.28. No.2. P.261266. doi: 10.15298/arthsel. 28.2.09

PЕЗЮМЕ. Новый вид Pancorius species, P. nagaland Caleb sp.n. (†), диагностирован и описане из северо-восточной Индии. Три вида: Pancorius darjeelingianus Prószyński, 1992, P. magnus Żabka, 1985 и P. tagorei Prószyński, 1992 илююстрированы и прокартированы. Предложены новая комбинация и синонимия: Pancorius pseudopaykulli Sen, Dhali, Saha et Raychaudhuri, 2015, comb.n. (еx Plexippus), и syn.n., как младший синоним $P$. darjeelingianus Prószyński, 1992.

\section{Introduction}

The plexippine genus Pancorius was erected by Simon in 1902, with Ergane dentichelis Simon, 1899 as its generotype. Currently, 34 valid Pancorius species are known from the Oriental Region [WSC, 2018], of which five species have been recorded/described from India: viz., $P$. daitaricus (Prószyński, 1992), $P$. darjeelingianus Prószyński, 1992, P. magnus Żabka, 1985, P. submontanus Prószyński, 1992 and P. tagorei Prószyński, 1992 [Prószyński, 1992]. The species, Pancorius dabanis (Hogg, 1922) was described and known from South Annam in Vietnam only, but its distribution is erroneously mentioned as India in the World Spider Catalog [WSC, 2018]. The aims of the present paper are (1) to describe a new species from north-eastern India; (2) to provide records of all the Pancorius species known to date from India; and (3) to propose a new combination and a synonymy.

\section{Material and methods}

Specimens were examined by means of a Leica EZ4 HD stereomicroscope. Micro-photographs were obtained by means of a Leica M205A stereomicroscope equipped with a Leica DFC500 HD camera and supported with a Leica Application Suite (LAS) version 3.8. Epigynes were dissected and cleared in $10 \% \mathrm{KOH}$. Temporary preparations were examined and photographed by means of a Leica DM1000 compound microscope equipped with a Leica EC3 camera. Leg measurements are given in the following order: total (femur, patella, tibia, metatarsus, tarsus). Spine positions are as follows: prolateral, dorsal, retrolateral and ventral. All measurements are in millimeters. The map was prepared in the DIVA-GIS (http://www.diva-gis.org). The examined voucher and type specimens are deposited in the Arachnida Section of the National Zoological Collections, Zoological Survey of India, Kolkata (NZC-ZSI) and the Centre for DNA Taxonomy, Zoological Survey of India, Kolkata (ZSICDT).

Abbreviations used in the text are as follows: AER anterior eye row; ALE - anterior lateral eye; AME anterior median eye; EFL - eye field length; D - described; PER - posterior eye row; PLE - posterior lateral eye; PME — posterior median eye. 

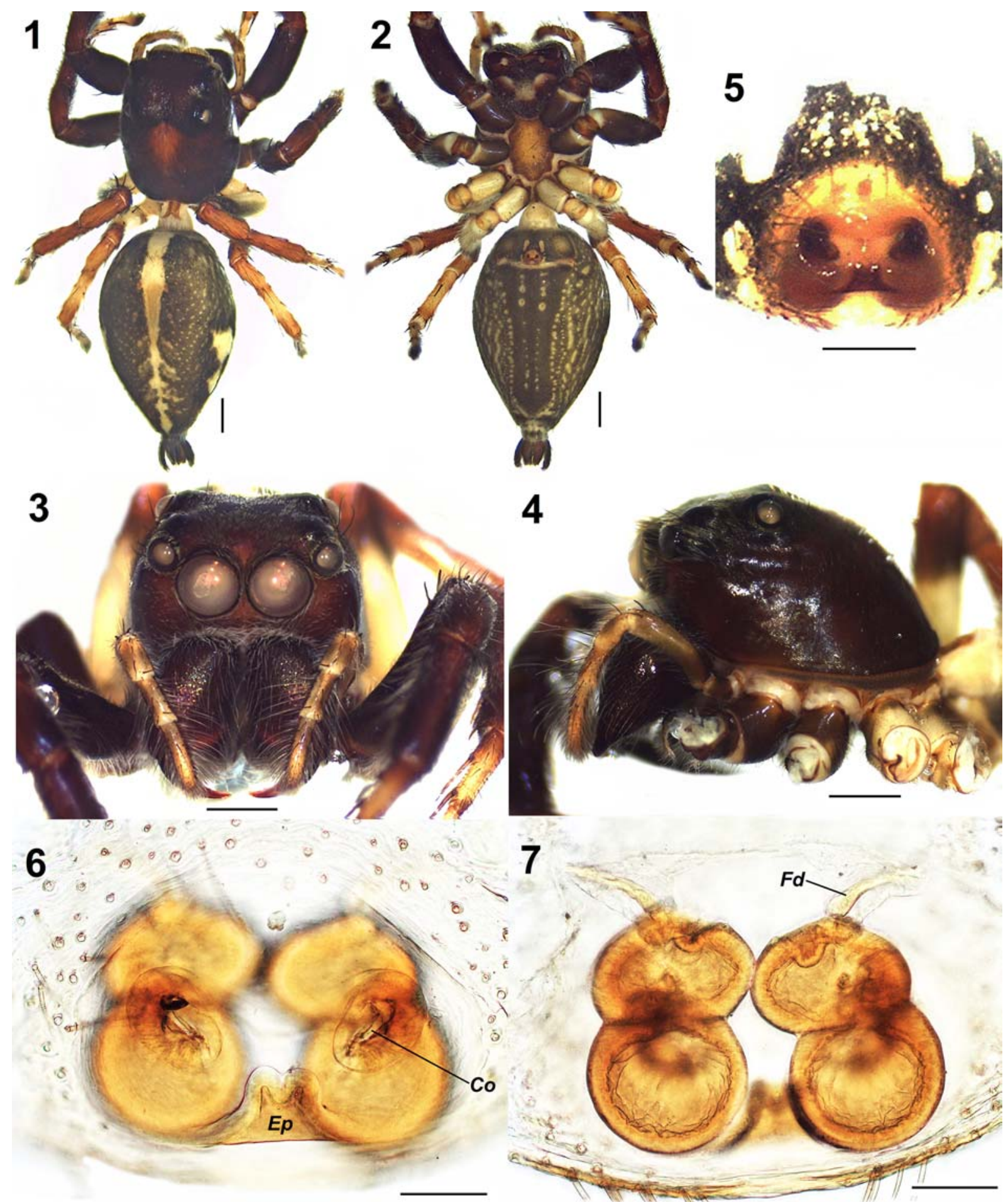

Figs 1-7. General appearance and copulatory organs of Pancorius nagaland sp.n., holotype female: 1 - general appearance, dorsal view; 2 - ditto, ventral view; 3 - front view; 4 - carapace, lateral view; 5 - epigyne, ventral view; 6 - cleared epigyne, ventral view; 7 - spermathecae, dorsal view. Scale bars $=(1-4) 1 \mathrm{~mm},(5) 0.25 \mathrm{~mm},(6-7) 0.1 \mathrm{~mm}$.

Abbreviations: Co — copulatory opening; Ep — epigynal pocket; Fd - fertilization duct.

Рис. 1-7. Общий вид и копулятивные органы Pancorius nagaland sp.n., самка-голотип: 1 - общий вид сверху; 2 - тоже, снизу; 3 - вид спереди; 4 - головогрудь, вид сбоку; 5 - эпигина, вид снизу; 6 - осветленная эпигина, вид снизу; $7-$ сперматека, вид сверху. Масштаб (1-4) 1 мм, (5) 0,25 мм, (6-7) 0,1 мм.

Сокращения: Сo - копулятивное отверстие; Ер — эпигинальный карман; $\mathrm{Fd}$ - оплодотворительный канал. 


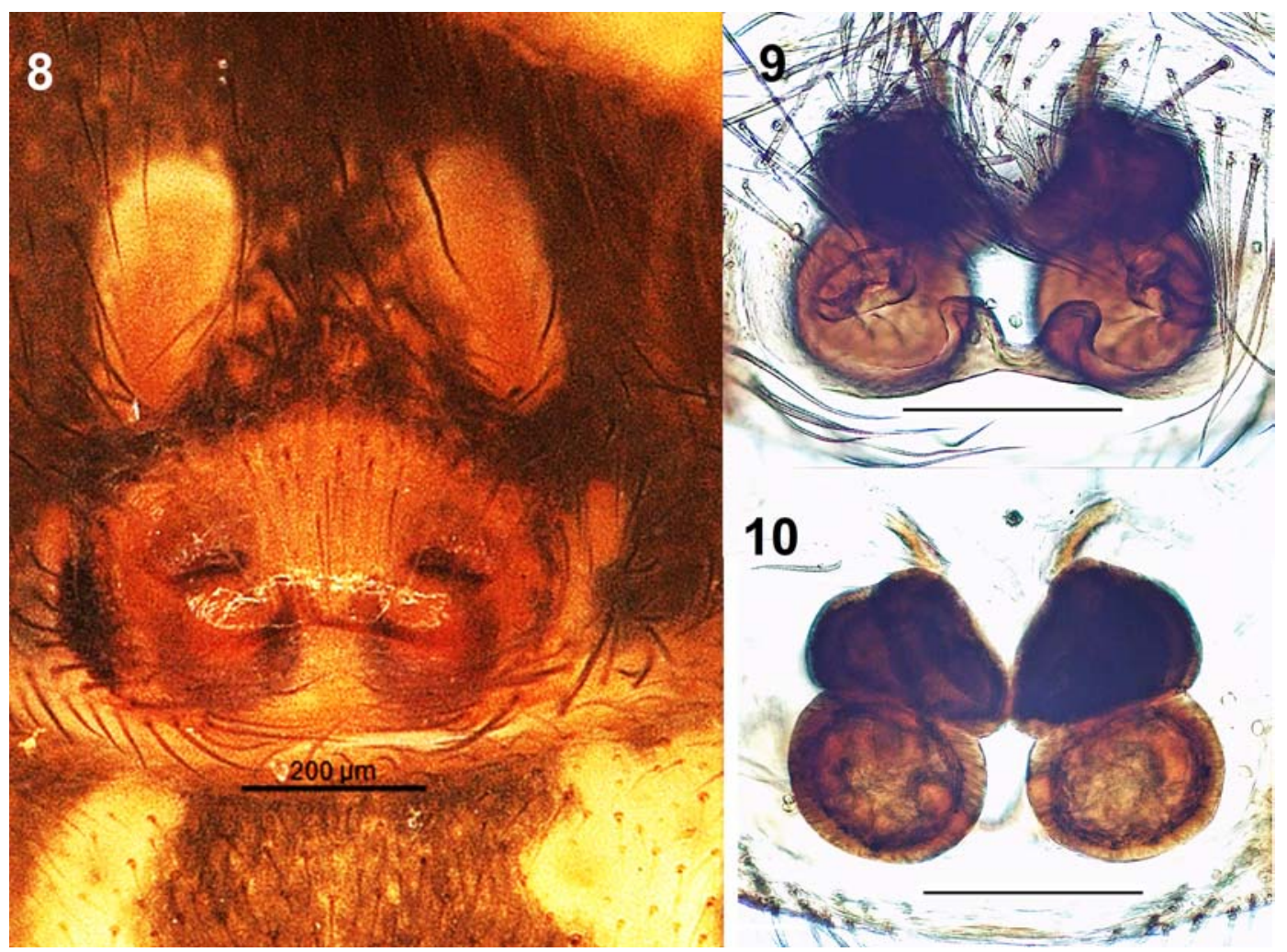

Figs 8-10. Copulatory organs of Pancorius darjeelingianus Prószyński, 1992: 8, 9 - epigyne, ventral view; 10 — spermathecae, dorsal view. Scale bars $=(9) 0.2 \mathrm{~mm}$.

Рис. 8-10. Копулятивные органы Pancorius darjeelingianus Prószyński, 1992: 8, 9 - эпигина, вид снизу; 10 — сперматека, вид сверху. Масштаб (9) 0,2 мм.

\section{Survey of species}

Genus Pancorius Simon, 1902

Pancorius nagaland Caleb, sp.n. Figs 1-7, 19-20, Map.

TYPES. Holotype + (NZC-ZSI-6449/18) from Intangki National Park $\left(25.663889^{\circ} \mathrm{N}, 93.512778^{\circ} \mathrm{E} ; 195 \mathrm{~m}\right.$ a.s.1.), Peren District, Nagaland, India, 25 March 2017, Swati \& Aneesh. Paratype: 1 o (NZC-ZSI-6460/18), Arunachal Pradesh, Tirap District, Gibbon's land, c. $16 \mathrm{~km} \mathrm{E}$ of Miao $\left(27.4882^{\circ} \mathrm{N}, 96.3576^{\circ} \mathrm{E} ; 701 \mathrm{~m}\right.$ a.s.1.; Namdapha Survey), 19 February 1982, S. Biswas.

ETYMOLOGY. Specific epithet is used as a noun in apposition taken from Nagaland, the Indian State where the type locality is situated.

DIAGNOSIS. The species can easily be distinguished from all the Pancorius species but $P$. minutus Żabka, 1985 by the shape and orientation of the copulatory openings (Figs 5-7, 19, 20). From the latter species, it can be separated by the median, M-shaped epigynal pocket (wide and directed laterally in P. minutus); sub-equal spermathecal chambers (the posterior chamber is much smaller in $P$. minutus) (cf. Figs 5-7, 19, 20 with figs 401, 402 in Żabka [1985]). It can be distinguished from $P$. tagorei by the slitshaped copulatory openings (Figs 6, 19) (semilunar in $P$. tagorei; Figs 17, 21); two spermathecal chambers without developed channels (Figs 7, 20) (three distinct chambers in P. tagorei; Figs 18, 22).
DESCRIPTION. Female (holotype). Total length: 10.28; carapace: 4.27 long, 3.39 wide; abdomen: 6.01 long, 3.91 wide. Carapace reddish brown, clothed with pale hairs (Fig. 1) and with two pairs of small tubercles occurring along the margin of the ocular area, one between the ALEs and PMEs and the other near the PLEs (Fig. 4). Black around posterior eyes. Anterior eyes surrounded by yellowish orbital setae. Clypeus is covered with white hairs (Fig. 3). Eye measurements: AME 0.92, ALE 0.48, PME 0.12, PLE 0.42, AER 2.70, PER 2.55, EFL 1.77. Clypeus height 0.23. Sternum light brown. Chelicerae reddish brown, with two teeth on the promargin and one tooth on the retromargin; labium and maxillae yellowish brown (Fig. 2). Legs yellowish brown; femora patellae and tibiae of legs I \& II reddish brown; femora III \& IV with lighter, yellowish proximal portion and dark brown distal portion (Figs 1, 2). Leg measurements: I $9.00(2.79,1.75,2.10,1.43,0.93)$; II $8.47(2.79,1.66,1.79$ $1.37,0.86)$; III $10.27(3.55,1.67,2.00,1.97,1.08)$; IV 9.71 $(3.25,1.28,2.04,2.19,0.95)$. Leg formula: 3412 . Spination of legs: femora I 1600, II 1600, III 0700, IV 0500; patellae I 0000, II 0000, III-IV 1010; tibiae I 2006, II 2016, III 3023, IV 3033; metatarsi I 0004, II 0004, III 3034, IV 4034; tarsi I-IV 0000. Abdomen brownish, with a median yellowish longitudinal stripe; mid-dorsal region with light brown chevron-shaped markings; lateral margins of abdomen with yellow patches; venter brownish, with yellow-brown spots. Spinnerets brownish (Figs 1,2). Epigyne and its internal structure as in Figs 5-7, 16-17.

Male unknown. 

(Map).

DISTRIBUTION. India (Nagaland, Arunachal Pradesh)

Pancorius darjeelingianus Prószyński, 1992 Figs 8-10, Map.

Pancorius darjeelingianus Prószyński, 1992: 190, figs 106108 ( $\mathrm{D}_{+}$; the $q$ in the Hungarian Natural History Museum, Budapest, not examined).

Plexippus pseudopaykulli Sen, Dhali, Saha et Raychaudhuri, 2015: 32, figs 77-81, pl. 13 ( $\mathrm{D}$; ; the 9 in the Ramakrishna Mission Vivekananda University, Narendrapur, Kolkata, digital images of a paratype - both the copulatory organs and general appearance examined), comb.n., syn.n.

Plexippus pseudopaykulli: Dhali et al., 2017: 28, figs 28-32, pl. 18 (+); Prószyński, 2017: 63, figs. 2T, 6L ( + , referred to this species as "unrecognizable", species inquirenda, probably nomen dubium).

MATERIAL. INDIA: 1 (NZC-ZSI), West Bengal, Rajabhat, Buxa Wildlife Sanctuary $\left(26.6148^{\circ} \mathrm{N}, 89.5336^{\circ} \mathrm{E} ; 77 \mathrm{~m}\right.$ a.s.1.), 23 March 2018, A. Rameshkumar.

COMMENTS. Plexippus pseudopaykulli was described from the holotype female and eight paratype females collected from the Gorumara National Park, which is located in the northern part of West Bengal [Sen et al., 2015]. Later, the species was repeatedly illustrated by Dhali et al. [2017]. The species was misclassified though and is better placed in Pancorius, since it shares such the diagnostic characters thereof as the slit-like copulatory openings on the sclerotized epigynal plate, the presence of the medial epigynal pocket and the three-chambered spermathecae. The authors' idea of $P$. pseudopaykulli seemed to vary a little, as the epigyne illustrated by Dhali et al. [2017: fig. 31] shows the semilunar copulatory openings being identical to those of $P$. tagorei (cf. Figs 18, 22 and fig. 127 in Prószyński, 1992). However, the female from the Buxa Wildlife Sanctuary studied in the present work (Figs 8-10) is found to be identical with the digital images of the copulatory organs of $P$. pseudopaykulli (presumably of the paratype) provided to JC by Prof Dinendra Raychaudhuri, the author of the latter species. Both the specimen from Buxa Wildlife Sanctuary and the paratype of $P$. pseudopaykulli (based on its images) are identical with $P$. darjeelingianus having its main diagnostic character: viz., the slit-like copulatory openings surrounded by a lip-like lining (Fig. 9) (in P. tagorei, only anterior lips present, posterior region without a distinct lip but with a simple groove-like passage; Figs 17, 21). The only minor difference observed is the shape of the median epigynal pocket, which has a visibly deeper depression in its middle (cf. Figs 8-10 with figs 107, 108 in Prószyński, 1992). Therefore, it is safe to conclude that the name $P$. pseudopaykulli is to be synonymized with $P$. darjeelingianus.

DISTRIBUTION. India (West Bengal) (Map).

Pancorius magnus Żabka, 1985

Figs 11-14, Map.

Pancorius magnus Żabka, 1985: 422, figs 387-400 (D ${ }^{7}$ ) Pancorius magnus: Prószyński, 1992: 191, figs 109-112 (O $)$; Peng \& Li, 2002: 340, figs 9-15 ( $\sigma^{7}$ ); Jastrzębski, 2011: 186, figs $9,20\left(\mathrm{O}^{7}\right)$.

MATERIAL. INDIA: $3 \sigma^{\top} \sigma^{\top}$ (ZSI-CDT-AA-1058, 1059, 1061), 2 우 (ZSI-CDT-AA-1060, 1062), Assam, Tinsukia, Bherjan-Borajan-Padumoni Wildlife Sanctuary $\left(27.5227^{\circ} \mathrm{N}, 95.3647^{\circ} \mathrm{E}\right), 30$ March 2017, Shantanu Kundu \& Devkant Singa; 1 क (NZC-ZSI6459/18), Arunachal Pradesh, Tirap Dist. (Namdapha survey), c. $27 \mathrm{~km}$ E of Miao, Deban (27.5405 $\mathrm{N}, 96.3974^{\circ} \mathrm{E} ; 481 \mathrm{~m}$ a.s.1.), 14 December 1982, S. Biswas \& Party.
DISTRIBUTION. India (West Bengal, Assam, Arunachal Pradesh), Nepal, Taiwan and Vietnam (Map).

Pancorius tagorei Prószyński, 1992

Figs 15-18, 21-22, Map.

Pancorius tagorei Prószyński, 1992: 193, figs 125-128 (D ${ }^{7}+$ ). MATERIAL. INDIA: $1 \sigma^{7}$ (NZC-ZSI-6530/18), South Range, Mahananda Wildlife Sanctuary, Jalpaiguri $\left(26.8066^{\circ} \mathrm{N}, 88.3992^{\circ} \mathrm{E}\right.$; $151 \mathrm{~m}$ a.s.1.), 9 November 2017; 1 ( (NZC-ZSI-6639/18), Dhoopjhar beat, South Gorumara Range, Gorumara National Park $\left(26.7306^{\circ} \mathrm{N}\right.$, $88.8046^{\circ} \mathrm{E} ; 184 \mathrm{~m}$ a.s.1.), 4 November 2017 , all leg. M.E. Hassan \& party.

DISTRIBUTION. India (West Bengal) (Map).

Acknowledgements. We are grateful to Dr Kailash Chandra, Director, Zoological Survey of India for his support and for providing us with the necessary facilities to carry out the work. We thank the Nagaland Forest Department for their kind support. We also wish to thank Dr P.T. Aneesh and Ms Swati for collecting specimens from Nagaland and Dr A. Rameshkumar for providing material collected from Buxa Wildlife Sanctuary, West Bengal. Avas Pakrashi is thanked for his help in preparing the map. Prof Dinendra Raychaudhuri of the Ramakrishna Mission Vivekananda University, Narendrapur, West Bengal, is thanked for providing us with the digital images of $P$. pseudopaykulli. John Caleb is grateful to the American Arachnological Society for the Herb Levi Memorial Fund for Arachnological Research (HLMFAR). Our sincere thanks go to Dr Dmitri Logunov (Manchester, UK) for patiently reviewing the ms and providing us with constructive comments.

\section{References}

Dhali D.C., Saha S., Raychaudhuri D. 2017. Litter and ground dwelling spiders (Araneae: Arachnida) of reserve forests of Dooars, West Bengal // World Scientific News. Vol.63. P.1242.

Jastrzębski P. 2011. Salticidae from the Himalayas. The genus Pancorius Simon, 1892 (Arachnida: Araneae) // Genus. Vol.22. P.181-190.

Peng X.J., Li S.Q. 2002. Four new and two newly recorded species of Taiwanese jumping spiders (Araneae: Salticidae) deposited in the United States // Zoological Studies. Vol.41. P.337-345.

Prószyński J. 1992. Salticidae (Araneae) of India in the collection of the Hungarian National Natural History Museum in Budapest // Annales Zoologici, Warszawa. T.44. P.165-277.

Prószyński J. 2017. Remarks on the genus Plexippus C. L. Koch, 1846 (Araneae: Salticidae) // Ecologica Montenegrina. Vol.13. P.39-69.

Sen S., Dhali D.C., Saha S., Raychaudhuri D. 2015. Spiders (Araneae: Arachnida) of Reserve Forests of Dooars: Gorumara National Park, Chapramari Wildlife Sanctuary and Mahananda Wildlife Sanctuary // World Scientific News. Vol.20. P.1-339.

Simon E. 1902. Etudes arachnologiques. 31e Mémoire. LI. Descriptions d'espèces nouvelles de la famille des Salticidae (suite) // Annales de la Société Entomologique de France. Vol.71. P. 389-421.

WSC. 2018. World Spider Catalog. Natural History Museum Bern, online at http://wsc.nmbe.ch, version 19.5. [accessed $24 \mathrm{Au}-$ gust 2018].

Żabka M. 1985. Systematic and zoogeographic study on the family Salticidae (Araneae) from Viet-Nam // Annales Zoologici, Warszawa. T.39. P.197-485.

Responsible editor D.V. Logunov 

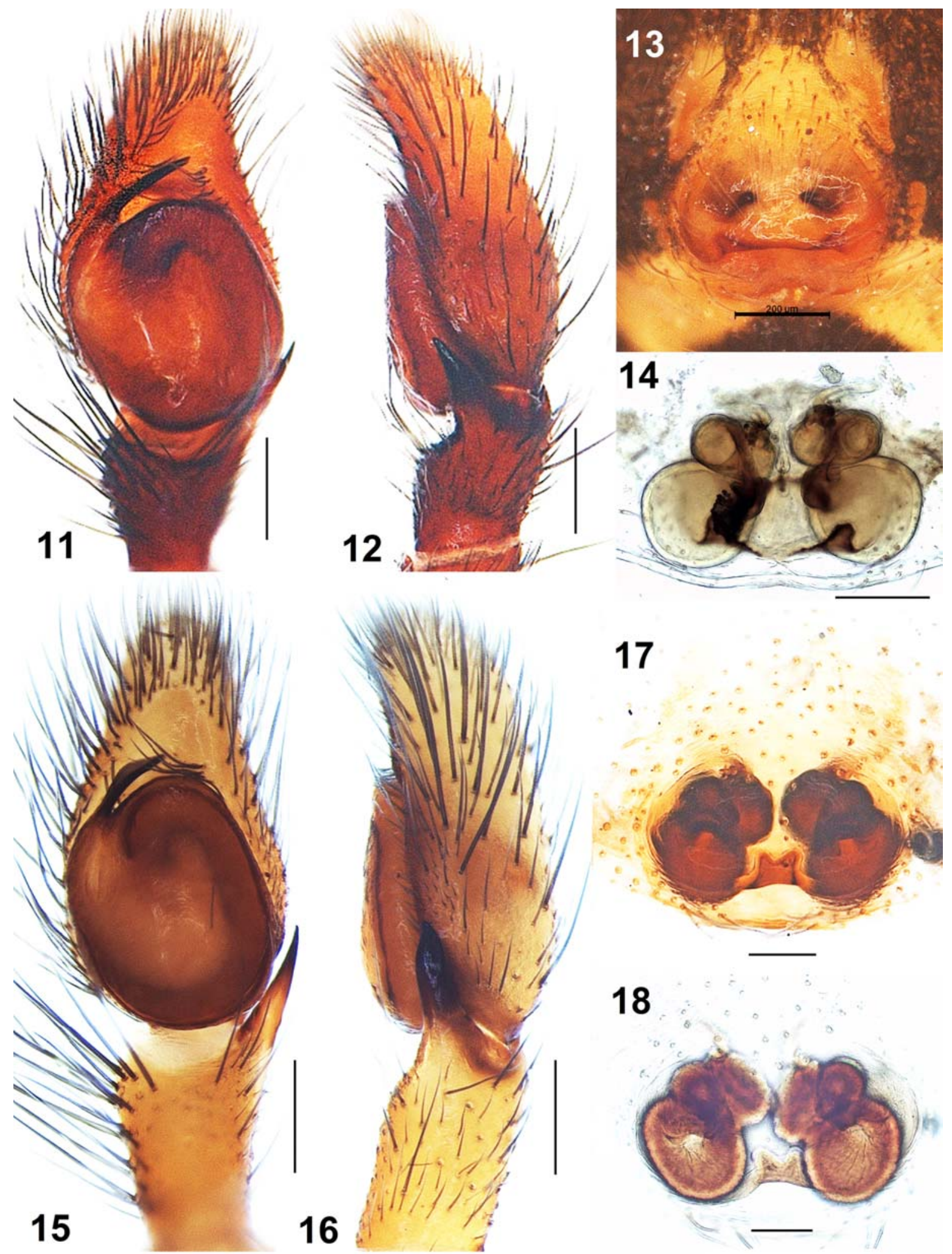

Figs 11-18. Copulatory organs of Pancorius magnus Żabka, 1985 (11-14) and P. tagorei Prószyński, 1992 (15-18): 11, 15 — male left palp, ventral view; 12,16 - ditto, retrolateral view; 13, 17 - epigyne, ventral view; 14,18 - spermathecae, dorsal view. Scale bars $=$ $(11-13,15,16) 0.2 \mathrm{~mm} ;(17,18) 0.1 \mathrm{~mm}$.

Рис. 11-18. Копулятивные органы Pancorius magnus Żabka, 1985 (11-14) и P. tagorei Prószyński, 1992 (15-18): 11, 15 — левая пальпа самца, вид снизу; 12, 16 - тоже, вид сбоку-сзади; 13, 17 - эпигина, вид снизу; 14, 18 - сперматека, вид сверху. Масштаб $(11-13,15,16) 0,2$ мм; $(17,18) 0,1$ мм. 

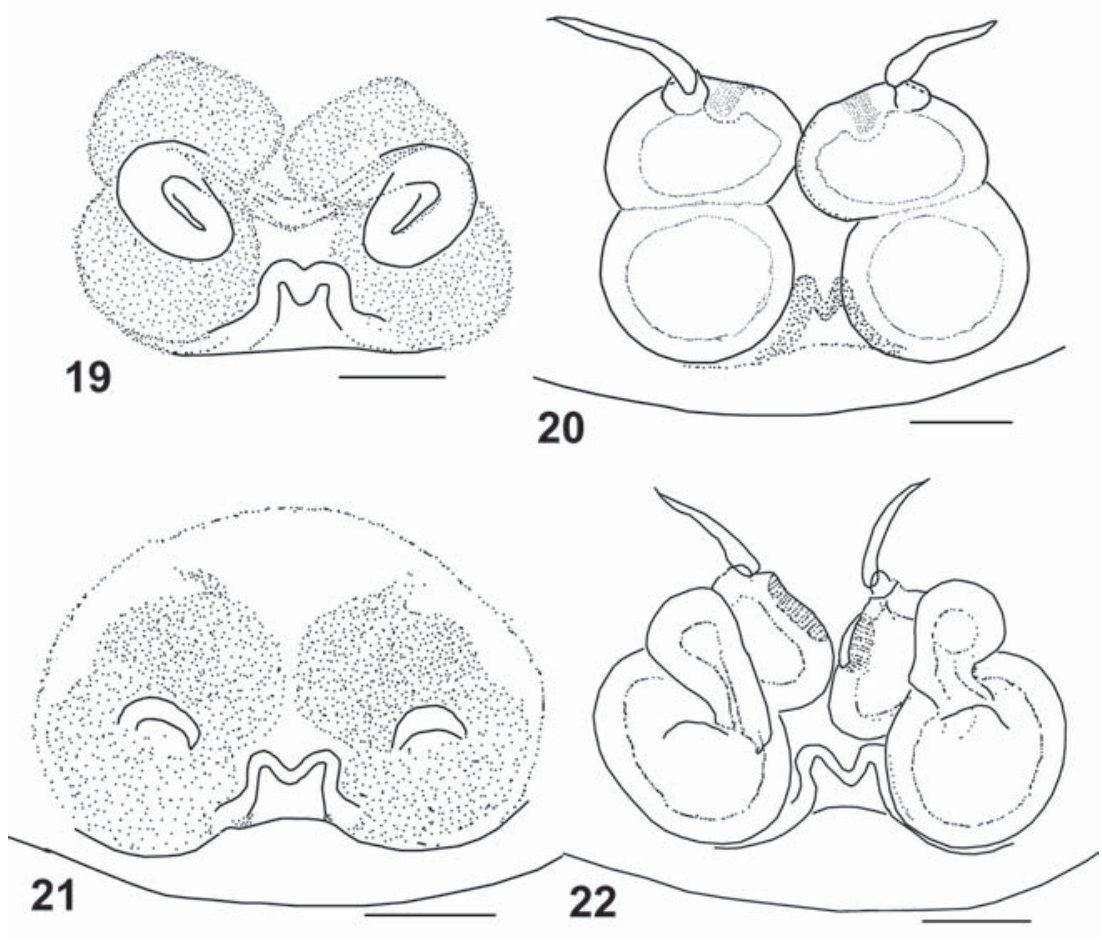

Figs 19-22. Copulatory organs of Pancorius nagaland sp.n. (19-20) and P. tagorei Prószyński, 1992 (21-22): 19, 21 - epigyne, ventral view; 20, 22 - spermathecae, dorsal view. Scale bars $=0.1 \mathrm{~mm}$.

Рис. 19-22. Копулятивные органы Pancorius nagaland sp.n. (19-20) и P. tagorei Prószyński, 1992 (21-22): 19, 21 — эпигина, вид снизу; 20, 22 - сперматека, вид сверху. Масштаб 0,1 мм.

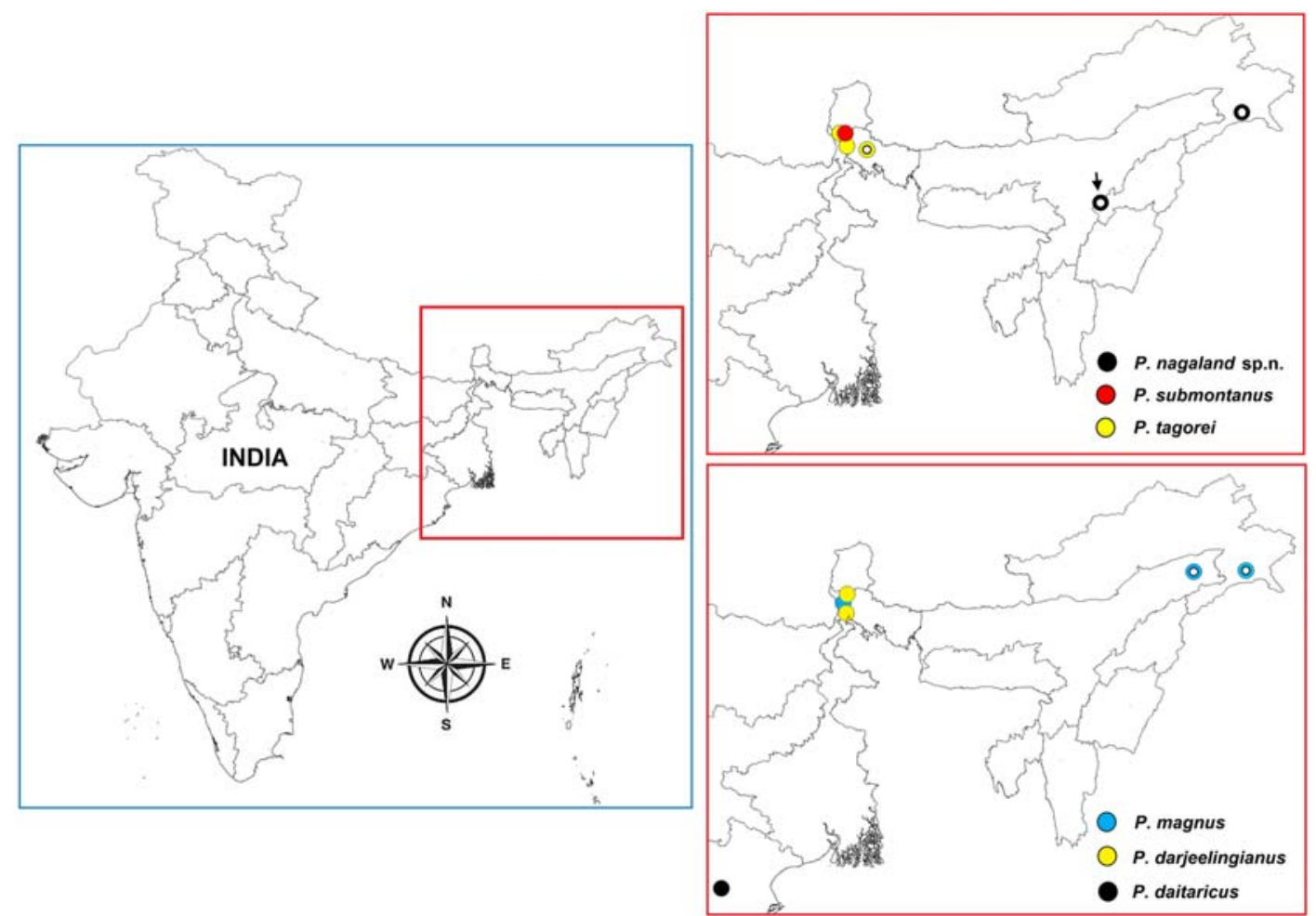

Map. Collecting localities of Pancorius species described/recorded from India. Full circles represent records from the literature. The circles having inner circles represent original data. The type locality of the new species $P$. nagaland sp.n. is arrowed.

Карта. Точки находок видов Pancorius описанных/отмеченных из Индии. Заполненные кружочки представляют литературные данные. Кружочки, имеющие внутренние кружочки, представляют оригинальные данные. Типовой локалитет нового вида $P$. nagaland sp.n. помечен стрелкой. 